\title{
How the global economy reflected the year of the pandemic
}

\author{
Vladislav Kaputa ${ }^{1, *}$, Frederik Kvočák ${ }^{1}$, Miroslava Triznová $^{1}$, Andrej Tomić ${ }^{1}$, and Hana \\ Mat'ová ${ }^{1}$ \\ ${ }^{1}$ Technical University in Zvolen, Dept. of Marketing, Trade and World Forestry, T, G. Masaryka 24, \\ 96001 Zvolen, Slovakia
}

\begin{abstract}
Research background: The coronavirus pandemic in 2020 had a significant impact on all aspects of life, from the point of view of the individual by forcing social isolation, moving work and study to the home, enormous pressure on the social and health system, but also by forcing closures of services and direct contact with customers. These, as well as other factors, have also had an impact on the performance of economies around the world. Purpose of the article: The paper aims to evaluate the development of the world's major economies in terms of macroeconomic indicators and foreign trade in the pandemic period and previous periods. The social and environmental aspects of the impact of the pandemic on selected economies are also reflected.

Methods: Analysis of the main macroeconomic data, comparison and synthesis of findings.

Findings \& Value added: The interdependence of economies and interconnectedness of markets on transport routes associated with reduced mobility, forced isolation of people and death of economic activity had a significant impact on all the observed indicators, where a significant decline in GDP could be observed in all countries except China. This country was the only one that managed to keep GDP growth in positive numbers. Unemployment development was not equal in the observed economies due to different labour market environment. On the contrary, the environment has benefited in some way.
\end{abstract}

Keywords: global economy; macroeconomics; foreign trade; pandemics

JEL Classification: E01; E66; F40

\footnotetext{
*Corresponding author: kaputa@tuzvo.sk
} 


\section{Introduction}

The world, even after a pandemic shock, remains globalized. In addition, amid renewed virus outbreaks, global growth continues to recover. OECD (2021) projecting global output to rise by nearly $6 \%$ in 2021 , but the global economy remains below its pre-pandemic growth path and in many OECD countries living standards by the end of 2022 will not be back to the level expected before the pandemic. However, the pandemic affected the depth (fragility) of international partners' relations, the links between sectors, and dependence on international transport routes is fully visible. Such interconnectedness and the need for accessibility of transport routes has proved to be the Achilles heel of world trade. This was underlined by the blockade of the Suez Canal by Ever Given (a cargo ship) in March 2021. Hošoff (2020) stated that the consumption growth and to globalization related offshoring and outsourcing, built with the aim of optimizing costs, were most affected. Transport and service systems were revealed in times of pandemic, as the weak point of current trade.

Stiglitz (2017) explains globalization simply: "it is nothing more, than an even greater integration of the countries of the world, and the more integrated the countries, the more interdependent they are". The strengthening of the role of the nation states, which applied restrictive measures to an unprecedented extent, examined the cohesion of the members of the various integration units. Also, the unprecedented protective policy net was deployed by governments to preserve the economies. Despite independent states, integration clusters are playing an increasingly important role. This can be seen in the example of the EU, where there is huge funding to support national recovery programmes.

After being sober from the initial fear of health and the adaptation of the population to the new situation, pandemic regulations have brought about a marginalization of moods in societies. Most of the communication was expressly transferred to the online space. This was possible thanks to the dynamic development of technology and significant technical progress of the previous period. The change was predictable in the education environment as well as in other parts of society, but no one expected such a rapid implementation of the processes leading to digitalization.

\section{Methods}

The methods used can be listed as follows: analysis of the problem, analysis of quantitative data, comparison, synthesis of findings. Using statistical data available in databases, we interpreted their values and tried to explain the causes and contexts of the development of the presented data by comparison with previous periods. The analyses are focused on the main world economies: USA, China, Japan and Germany. In addition, the EU average is taken into account as well. Data from the databases of the International Monetary Fund, the World Trade Organization and the World Bank are used to evaluate the indicators. Year 2021 is estimated (by the given data source). We analysed the following indicators: GDP, inflation, unemployment, business environment index, and foreign trade (as total merchandise exports).

The GDP indicator refers to the productive output of the economy (goods and services produced) per year. It also tells about the average standard of living on earth, although critics of this indicator argue that it does not take into account the income structure (Escosura, 2017). In addition, the costs of negative externalities are included. Real GDP evaluates goods and services produced in a given country at previous year's prices, thus adjusting them for inflation. In comparison, we use GDP per capita in Purchasing Power Parity (PPP), which takes into account the price level in a given country. PPP is a unit of conversion, expressing the ratio of the price of goods and services in national currency to the price in the currency 
of the country being compared. These are mainly immobile goods such as services or labour (Holman, 2005 pp. 425-430).

Inflation points to an increase of the price level, or points to a decrease in the money purchasing power. In the study, we use the Consumer Price Index (CPI), which monitors inflation based on universal consumer basket, which contains a set of selected goods and services, covering a wide range of consumption.

Unemployment is recorded by able-bodied persons willing to work, but who cannot find work on the labour market. It is measured by the unemployment rate expressing the ratio of the unemployed to the total labour force (all employed and unemployed),

Government debt refers how much a country owes to creditors. Public debt represents the accumulation of annual budget deficits, i.e. state budget revenues are lower than state expenditures. The probability that a country can repay its debt is indicated by the debt-toGDP ratio.

\section{Results}

\subsection{Real GDP growth}

China, continuously maintains GDP growth at around 7\%. Among the economic giants, it is the only one that has maintained positive GDP growth despite pandemic restrictions. The year-on-year GDP decline was at 3.5\%. In this country the pandemic began to spread in the beginning of 2020, to all over the world, but despite the strict lockdown, China was able to subsequently restore its productions capacities. As the main world distributor of medical equipment, the dependence of other countries, on the supply of these medical products, was confirmed.

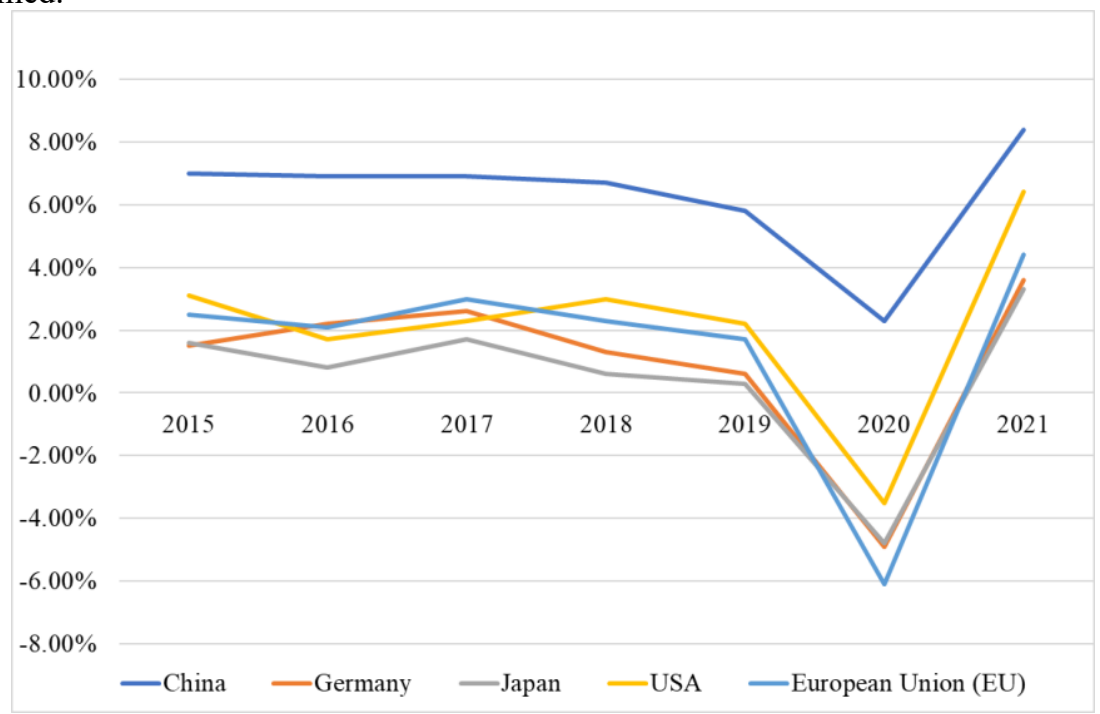

Figure 1. Real GDP growth (Annual percentage change); Year 2021 - estimated.

Source: based on data from the International Monetary Fund (2021)

The European Union, and Germany as its most efficient economy, struggled with stagnation. This is reflected by annual differences, where Germany slowed from $2.60 \%$ in 2017 , to $0.6 \%$ the end of 2019 . The pandemic reduced Germany's performance to $-4.9 \%$. The EU as a whole felt to $-6.10 \%$. This is significantly affected by the slowdown in economic 
activity throughout the Union, strict lockdowns based on particular situations in each EU countries.

Japan is already stagnated for a long time, both in economic and demographic terms. GDP growth has been below 1\% for the last two years, and in 2020 it fell more than 5\% (compared to 2019) to negative values. A situation where economic growth is slow, low inflation combined with low interest rates is referred to as Japanification of the economy.

The USA has been hit by a demand shock, caused by quarantine and unemployment. It is connected with supply weakening and the inability of the economy to produce as a result of measures. The USA showed a negative GDP (-3.5\%) in 2020, which is the lowest negative GDP rate of the all above mentioned countries, except China.

\subsection{Real GDP growth}

The comparison shows, that the USA as one of the largest economies in the world, achieves the highest nominal value of GDP per capita in PPP in the long term period. China keeps the lowest rate (Figure 2). However, only China achieved an increase in the nominal value of GDP (as well as a percentage growth in GDP) in the pandemic year 2020. In other countries, there has been a decline, mainly due to the weakening of international trade in the world and restrictive measures by national governments. The change ranged from $-3 \%$ to $-5 \%$ compared to the nominal value of 2019 , except for China, which improved by almost $3.2 \%$ year-onyear.

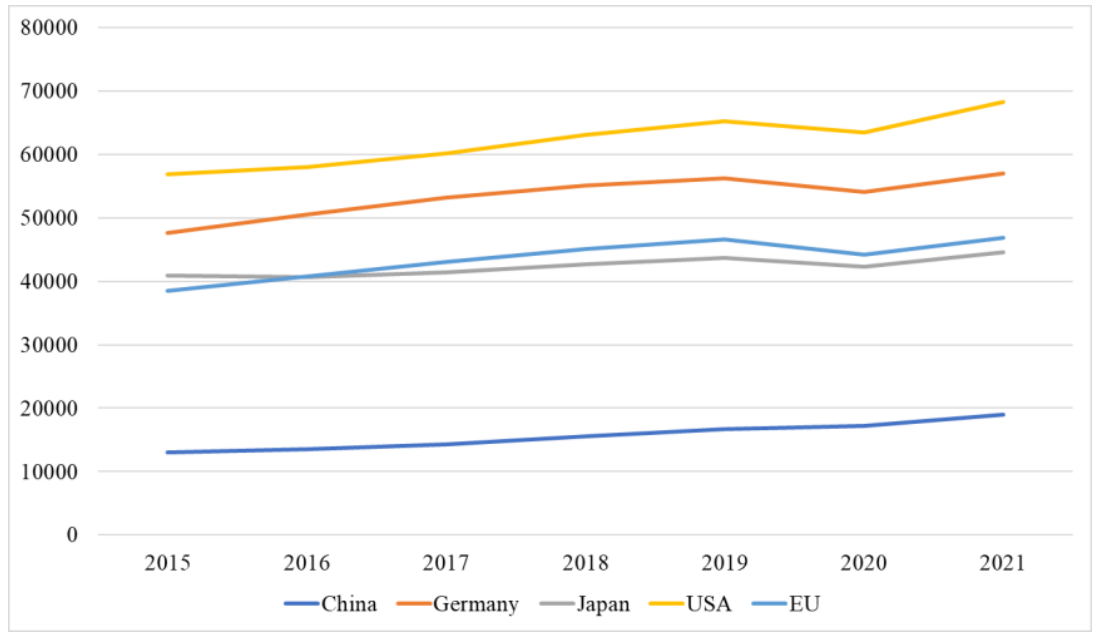

Figure 2. GDP per capita, current prices (Purchasing Power Parity; International dollars per capita); Year 2021 - estimated

Source: based on data from the International Monetary Fund (2021)

\subsection{Inflation}

Germany and the EU average have similar inflation rates. Germany reduced inflation by $1 \%$ year-on-year, similarly as the EU, which halved its inflation. China has a long-term stable inflation rate, despite a half-percent reduction in 2020 (the estimate for 2021 is even lower). Japan struggles with long time stagnation in several areas. It achieved inflation reaching $0 \%$ in 2020. In the case of the largest economy in the world, this value was $0.4 \%$ lower, when compared to 2019. We observed a year-on-year declining trend in inflation in these economies. Excluding China, inflation is expected to rise (Figure 3). 


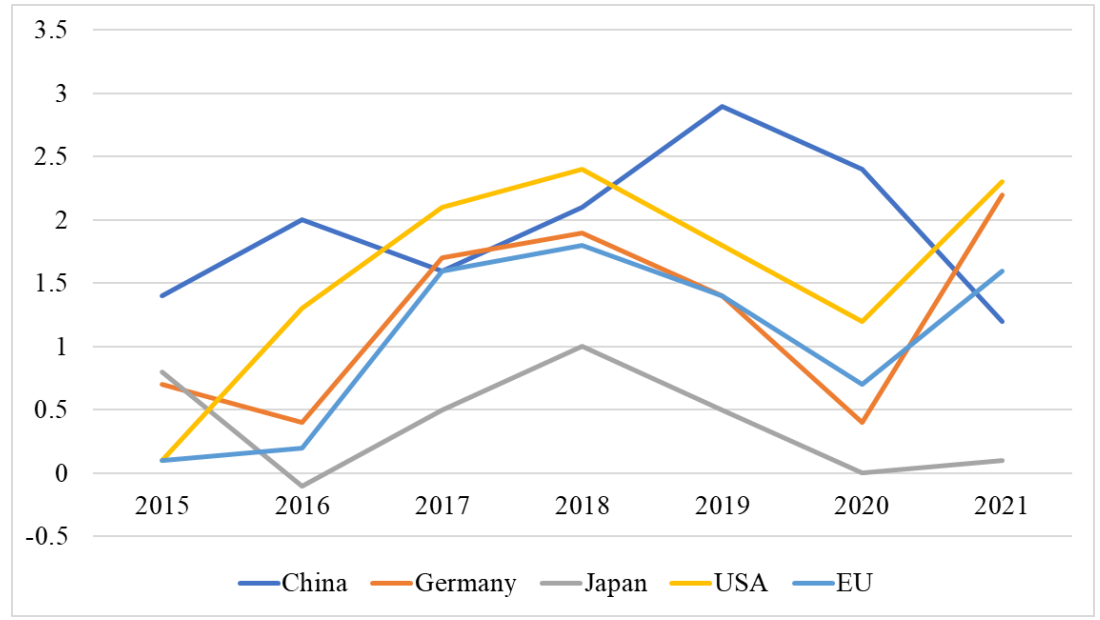

Figure 3. Inflation rate, average consumer prices (Annual percent change); Year 2021 - estimated.

Source: based on data from the International Monetary Fund (2021)

\subsection{Unemployment}

Economic units have not been able to manufacture and offer their products on the market due to restrictions on mobility and problems with supply systems. However, the corona crisis caused not only a shock on the supply side, but also on the demand side. It fell due to mandatory isolation of persons, lower incomes and rising unemployment. Declined demand focused on essential goods, and on medical and protective equipment. Government restrictions on the mobility of individuals have weakened economies as a whole, but the ban on commercial activities in the countries, has significant impact on service-oriented economies.

Unemployment rose in all the observed economies, but it rose the most, in the US, to $8.1 \%$. This is due to the nature of the US labour market, which is very flexible. Compared to European countries, there is no such emphasis on the employment protection. This is indicated by the level of unemployment in Germany and the EU as a whole, with an increase in unemployment of around 1\%. However, unemployment is a long-term problem for southern European countries such as Italy, Spain and Greece. Here, youth unemployment has reached almost $50 \%$. EU countries have focused on maintaining jobs by temporarily supporting employers who were unable to run their businesses due to the pandemic. In Germany, the Kurtzarbeit fund is used for this. In Japan and China, we see only a slight increase of the unemployment rate in 2020 (Figure 4). This was caused by the quick recovery of the economy and the timely management of the crisis. 


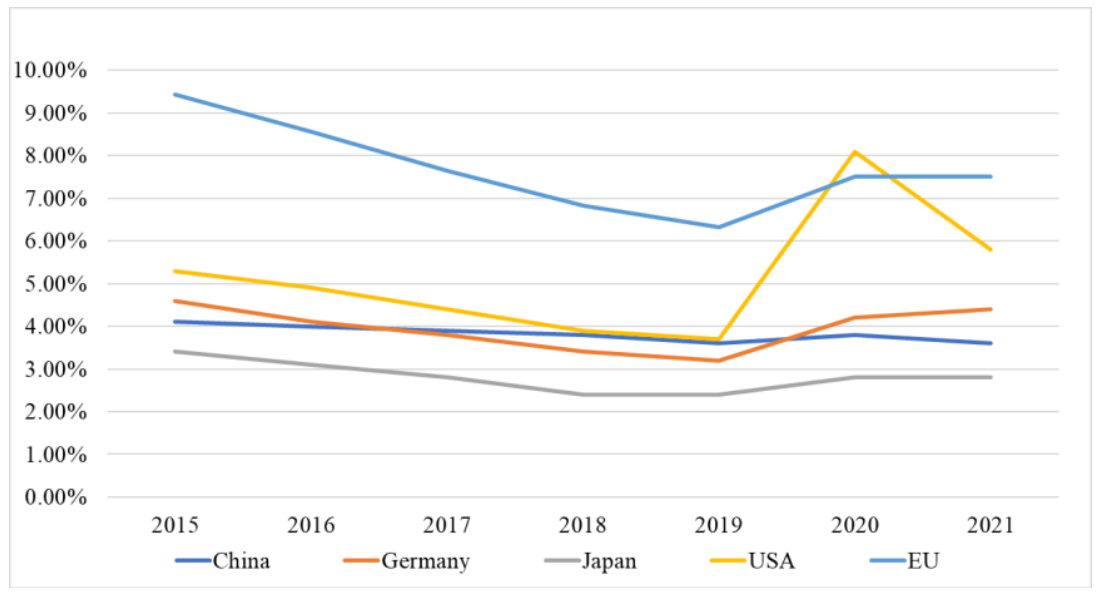

Figure 4. Unemployment rate; Year 2021 - estimated.

Source: based on data from the International Monetary Fund (2021)

\subsection{Government debt}

The fiscal policy plays key role, when dealing with economic crisis. To support the aggregate demand, the concept of temporary tax reduction and increase of public investment is used (despite the negative impact on public finances as a consequence) (Czech et al., 2020). This is how the logic of governments, which maintain the economy through public investment in times of crisis, even at the cost of rising debt, can be interpreted. The debts of the US and Japan exceed the annual performance of their economies. In the case of Japan, up to 2.5 times. In all observing countries, debt increased in the range of 10-20 percentage points in 2020. The debt of the EU has increased to almost $92 \%$ also due to the policy of job preservation and the so-called hibernation of the economy. Germany has long maintained a balanced or surplus budget, reaching a debt level of $68.9 \%$ in 2020 . China's public debt also rose by almost 10 percentage points to $66.8 \%$

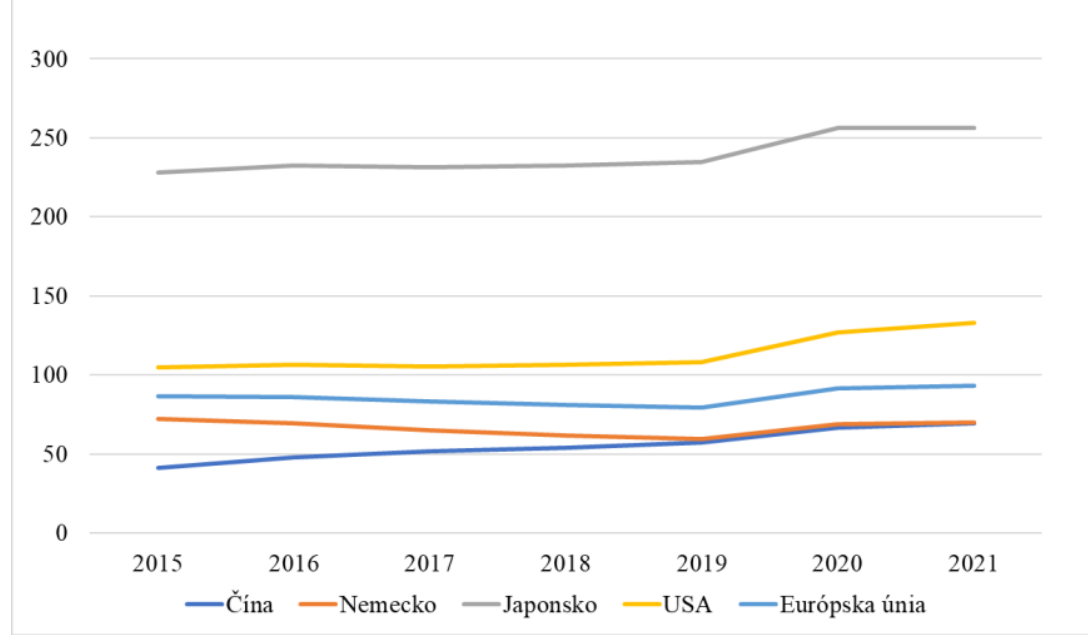

Figure 5. General government gross debt (Percent of GDP); Year 2021 - estimated.

Source: based on data from the International Monetary Fund (2021) 


\subsection{Foreign Trade}

The total merchandise exports decrease can be observed in most of economies, except of China (Figure 6). Trade between the United States and China itself is affected by the tariffs, introduced by the President Trump administrative, where a trade agreement has not yet been negotiated, nor was strengthened the wider economic integration of those two countries (WorldBank, 2021). The whole world foreign trade decreased by almost $8 \%$ due to restricted economic activities. The transport sector was hit hardest, due to mobility restrictions. The interdependence of the world's economies and their dependence on the international transport of goods has caused, that almost $75 \%$ of companies experienced discountenance in their supply chain (Fernandes, 2020).

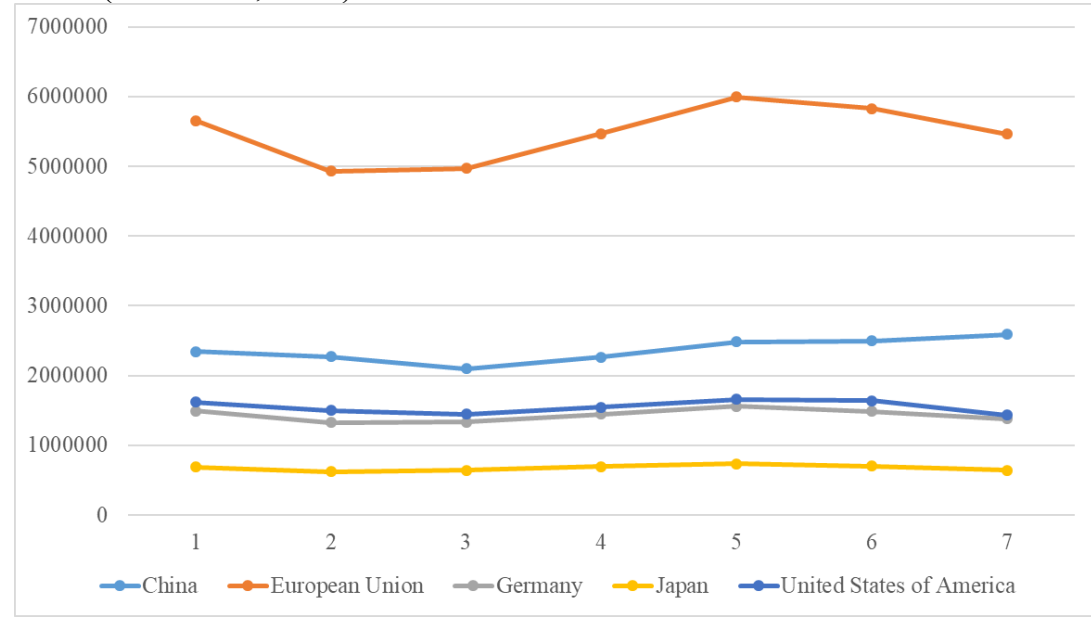

Figure 6. Total merchandise exports - Annual in million US dollar.

Source: based on the WTO data (2021)

\section{Discussion and Conclusions}

The growth of consumption in the period from 1995 to 2000 led to the building of a huge range of production capacities and at the same time to a huge expansion of the global distribution of production and consumer activities (Hošoff, 2020). Due to the globalization and interconnection of economies the companies were required to be constantly innovative (Loucanova et al., 2017). Hošoff (2020) stated that a complex system of subcontracting, offshoring and outsourcing has been created in the mentioned period. This has made it possible to optimize production and production costs, but at the same time has increased the company's huge vulnerability in terms of transport and service systems. Here, the COVID19 pandemic broke out at a time when there were heightened uncertainties in the global economy (Song and Zhou, 2020). The contagious disease has limited people to its homes which in turn affected the daily working life of the citizens. Unlike the other pandemics, it has an unprecedented impact on the labour market and consumer market (Zongyun et al., 2021).

Coutino and Zandi (2021) estimated the loss of production capacity for the global economy and for the two main world locomotives, the U.S. and China. But the rapid recovery of the Chinese economy proved by analyses is a point to think about. Korneta and Rostek (2021) stated that the more severe the development of the pandemic, the more adaptive to its negative effects the economies eventually became. 
One of the key lessons of this crisis is to pay more attention to the resilience of supply chains, as underlined by the price spikes in sectors where production is overly concentrated. The world economy is currently navigating towards the recovery, with lots of frictions. The risk that sufficient post-pandemic growth is not achieved or widely shared is elevated. This will very much depend on the adoption of flexible and sustainable policy frameworks, and on the quality of international cooperation (OECD, 2021). Contractor (2021) claims that the changes (caused by pandemic) induced by heightened nationalism and protectionism will be marginal rather than fundamental in nature. He argues that these marginally higher risks can easily be handled and ameliorated by multinational enterprises through alternate cross-border business strategies and emerging technologies. Robinson (2020) sees global capitalism on the verge of the next round of restructuring and transformation based on a much more advanced digitalisation of the entire global economy and society. He argues that as restructuring proceeds, it will heighten the concentration of capital worldwide, worsen social inequality and aggravate international tensions.

While some authors are calling for rapid recovery of the global economy, other stated that this latest pandemic will compromise trends in globalization. Ciravegna and Michailova (2021) pointed at the growing global uncertainty and higher costs in international transactions. They argue that global value chains' reconfiguration will result in a less globalized, and more regionally fragmented world economy.

In addition to the negative impact of the coronavirus pandemic on economic indicators such as GDP, unemployment, national debt, international trade and, last but not least, the enormous impact on the health system, there is also a positive (although probably short-lived) environmental effect, that can be pointed out.

Restrictions on the movement of people, transport, industrial restrictions and mandatory isolation have significantly improved air quality, as seen in the first lockdown in China, which reduced social and economic activities, resulting in reduced energy consumption, reduced emissions and reduced air pollution in throughout China by $20-30 \%$, followed by 20 -year airborne dust minima in India and a $45 \%$ reduction in European cities such as Rome, Milan and Madrid (Ibn-Mohammed et al., 2021). Also with the need to isolate members of the population, there has been an accelerated digitization in education, in the work environment with the introduction of home office, and the transition of many businesses from services and sales to digital space.

\section{Acknowledgements}

The authors would like to thank the Scientific Grant Agency of the Ministry of Education, Science, Research and Sport of the Slovak Republic and the Slovak Academy of Sciences, grant number 1/0674/19: "Proposal of a model for the eco-innovation integration into the innovation process of companies in Slovakia in order to increase their performance" and grant number 1/0666/19: "Determination of the development of a wood-based bioeconomy".

\section{References}

1. Ciravegna, L., \& Michailova, S. (2021). Why the world economy needs, but will not get, more globalization in the post-COVID-19 decade. J Int Bus Stud.

2. Contractor, F. J. (2021). The world economy will need even more globalization in the post-pandemic 2021 decade. J Int Bus Stud.

3. Coutino, A. \& Zandi, M. (2021). Global loss of production capacity caused by the COVID-19 pandemic. Journal of Policy Modeling, 43(3), 493-502. 
4. Czech, K., Wielechowski, M., Kotyza, P., Benešová, I., \& Laputková, A. 2020. Shaking Stability: COVID-19 Impact on the Visegrad Group Countries' Financial Markets. Sustainability, 12(15), Article 6282.

5. Escosura, Prados de la. (2017). GDP, Income Distribution, and Welfare. In Spanish Economic Growth, 47-59. Palgrave Studies in Economic History.

6. Fernandes, N. (2020, March 23). Economic Effects of Coronavirus Outbreak (COVID19) on the World Economy. SSRN. https://ssrn.com/abstract $=3557504$

7. Holman, Robert. (2005). Ekonomie. Praha: C.H. Beck.

8. Hošoff, B. et al. (2020). Vývoj a perspektívy svetovej ekonomiky: Transformácia počas pandémie koronavírusu SARS-CoV-2. Ekonomický ústav Slovenskej akadémie vied.

9. Ibn-Mohammed T., Mustapha K. B., Godsell J., Adamu Z., Babatunde K. A., Akintade D. D., Acquaye A., Fujii H., Ndiaye M. M., Yamoah F. A., \& Koh S. C. L. (2021). A critical analysis of the impacts of COVID-19 on the global economy and ecosystems and opportunities for circular economy strategies. Resources, Conservation and Recycling, 164, Article 105169.

10. International Monetary Fund. (2021). IMF Data. https://www.imf.org/en/Data

11. Korneta, P., \& Rostek, K. (2021). The Impact of the SARS-CoV-19 Pandemic on the Global Gross Domestic Product. International Journal of Environmental Research and Public Health, 18(10), Article 5246.

12. Loucanova, E., Olsiakova, M., \& Dzian, M. (2017). Open innovation system in business process in the global market. The 17th International scientific conference Globalization and its socio-economic consequences 2017 (pp. 1347-1353).

13. OECD. (2021). OECD Economic Outlook, Volume 2021 Issue 1. https://www.oecdilibrary.org/economics/oecd-economic-outlook-volume-2021-issue-1_bb1b1db3-en

14. Robinson, W. I. (2020). Global capitalism post-pandemic. Race \& Class, 62(2), 3-13.

15. Song, L. \& Zhou, Y. (2020). The COVID-19 Pandemic and Its Impact on the Global Economy: What Does It Take to Turn Crisis into Opportunity? China \& World Economy, $28,1-25$.

16. Stiglitz, J.E. (2017). Euro. Praha: Knižní klub edice Universum.

17. World Bank. (2021). Gobal Economic Prospects. https://www.worldbank.org/en/publication/global-economic-prospects

18. WTO. (2021). WTO Stats. https://timeseries.wto.org/

19. Zongyun Li, Panteha Farmanesh, Dervis Kirikkaleli \& Rania Itani. (2021). A comparative analysis of COVID-19 and global financial crises: evidence from US economy. Economic Research-Ekonomska Istraživanja. 